\title{
Alleviation of Copper Toxicity in Arabidopsis thaliana by Silicon Addition to Hydroponic Solutions
}

\author{
Jie Li and Scott M. Leisner ${ }^{1}$ \\ Department of Biological Sciences, University of Toledo, Toledo, $\mathrm{OH} 43606$ \\ Jonathan Frantz \\ U.S. Department of Agriculture-Agricultural Research Service, Application Technology Research \\ Unit, Toledo, $\mathrm{OH} 43606$
}

\begin{abstract}
Additional IndeX words. Si, Cu, PAL, COPT1, HMA5
Abstract. Copper (Cu) is an essential micronutrient for plants and is the a.i. in pesticides for some pathogens and algae. Elevated doses of $\mathrm{Cu}$ can cause toxicity in plants. While silicon $(\mathrm{Si})$ is reported to alleviate the toxicity of some heavy metals, its role in reducing the symptoms induced by excess $\mathrm{Cu}$ is unclear. Therefore, the role of $\mathrm{Si}$ in plant response to $\mathrm{Cu}$ stress was investigated in arabidopsis [Arabidopsis thaliana (L.) Heyn.]. Based on plant symptoms (a reduction of leaf chlorosis as well as increased shoot and root biomass) and a reduction of phenylalanine ammonia lyase [PAL (EC 4.3.1.5), a stress-induced enzyme] activity in the shoot, Si was found to alleviate copper stress. Realtime reverse transcriptase-polymerase chain reaction analyses indicated that the RNA levels of two arabidopsis copper transporter genes, copper transporter 1 (COPT1) and heavy metal ATPase subunit 5 (HMA5) were induced by high levels of $\mathrm{Cu}$, but were significantly decreased when $\mathrm{Si}$ levels were also elevated. Taken together, our findings indicate that $\mathrm{Si}$ addition can improve the resistance of arabidopsis to $\mathrm{Cu}$ stress, and this improvement operates on multiple levels, ranging from physiological changes to alterations of gene expression.
\end{abstract}

The transition metal copper $(\mathrm{Cu})$ is an essential element for all organisms. Copper functions as a cofactor within plant cells in a variety of physiological processes, including electron transfer in photosynthesis, mitochondrial respiration, superoxide scavenging, lignification of cell walls, and ethylene sensing (Epstein and Bloom, 2005; Fox and Guerinot, 1998; Marschner, 1995). In addition to its role as an essential element, $\mathrm{Cu}$ is a potentially toxic agent at supraoptimal levels due to its ability to generate harmful reactive oxygen species (Sancenón et al., 2004).

Electrolytically generated $\mathrm{Cu}$, cupric sulfate, and copper hydroxide, as the active component of pesticides, bactericides, and fungicides, has been used in agriculture to control diseases and algae (Kaplan, 1999; Scheck and Pscheidt, 1998). For example, over 1.5 million kilograms of copper hydroxide was used on over 50 crops in California in 2005 (Kegley et al., 2007). Recent survey data indicated that the use of electrolytically generated $\mathrm{Cu}$ to control diseases and algae was increasing in the greenhouse industry (Zheng et al., 2004). Proper calibration of $\mathrm{Cu}$ generators and following labeling guidelines should reduce the risk of plants being exposed to excess $\mathrm{Cu}$. However, the increased use of $\mathrm{Cu}$-containing products carries an inherent risk of causing $\mathrm{Cu}$ toxicity.

To overcome $\mathrm{Cu}$ toxicity, plants possess a sophisticated homeostatic network controlling $\mathrm{Cu}$ uptake, utilization, and detoxification (for reviews, see Harrison et al., 2000; Puig and Thiele, 2002; Rees and Thiele, 2004). Regulation of uptake

Received for publication 10 Apr. 2008. Accepted for publication 12 June 2008. We thank the USDA-ARS for financial support.

We thank Douglas Sturtz and Alycia Pittenger for elemental analysis. We also thank Ying Deng for providing the actin primers, and Futong Yu and John Gray for their assistance.

The mention of a trademark, proprietary product, or vendor does not constitute a guarantee or warranty of the product by the USDA, and does not imply its approval to the exclusion of other products or vendors that also may be suitable. ${ }^{1}$ Corresponding author. E-mail: sleisne@utnet.utoledo.edu. through the plasma membrane is a key step controlling plant $\mathrm{Cu}$ homeostasis. This function is accomplished by a family of cellsurface, high-affinity $\mathrm{Cu}$ transporters, denoted copper transporter (COPT) (Sancenón et al., 2003). Subsequent intracellular distribution of $\mathrm{Cu}$ is mediated by $\mathrm{Cu}$ chaperones, which are soluble $\mathrm{Cu}$-binding proteins that direct the metal to its final destination. A plant ATX1-like protein participates in the delivery of $\mathrm{Cu}$ to a $\mathrm{Cu}$-transporting P-type ATPase located at the secretory pathway membranes, which is responsible for proper acquisition of $\mathrm{Cu}$ by membrane- and $\mathrm{Cu}$-containing proteins (Lin and Culotta, 1995; Lin et al., 1997). Among heavy metal-transporting P-type ATPases (HMAs), the protein encoded by the HMA5 gene is mainly expressed in pericycle cells (Birnbaum et al., 2003), and it is speculated to play a role in Cu transport from roots to shoots (Andrés-Colás et al., 2006). It is likely that other factors also play a role in $\mathrm{Cu}$ homeostasis.

The roles and requirements for silicon ( $\mathrm{Si}$ ) in plant biology have been debated for more than 150 years despite numerous reports describing its beneficial properties (Epstein, 1994, 1999; Fauteux et al., 2006; Williams and Vlamis, 1957). The most positive and consistent effects of $\mathrm{Si}$ are the alleviation of abiotic and biotic stress (Datnoff et al., 2007; Williams and Vlamis, 1957). For example, Si application can balance nutrient levels, especially heavy metals, in plant tissues. This is accomplished through the suppression of uptake of some nutrients, such as Mn (Horst and Marscher, 1978; Iwasaki et al., 2002a, 2002b, 2002c; Rogalla and Römheld, 2002a, $2002 \mathrm{~b}$ ), or by facilitating the uptake of others, such as $\mathrm{Zn}$ (Epstein and Bloom, 2005; Marschner, 1995). Compared with studies examining the effect of Si on Mn and $\mathrm{Zn}$, the effect of Si on $\mathrm{Cu}$ toxicity has not been studied widely. Therefore, the objective of this study was to examine the effects of $\mathrm{Si}$ on $\mathrm{Cu}$ detoxification with the model plant, arabidopsis. $\mathrm{Cu}$ toxicity was examined by a variety of parameters ranging from morphologic responses to changes in gene expression. 


\section{Materials and Methods}

Plant growth conditions and treatments. Seed holders were prepared by cutting off the conical end of $0.5-\mathrm{mL}$ microcentrifuge tubes (PCR Reaction Cap Strips; Fisher Scientific, Hanover Park, IL). Pieces of dry packing foam previously cleaned with hydrochloric acid and rinsed with distilled water were inserted into the tubes. The foam-filled tubes were saturated with nutrient solution under vacuum and placed into holes in small micropipette tip racks. Concentrations of elements and their primary sources in the nutrient solution were as follows: macronutrients $(\mathrm{mm}) 1.25 \mathrm{~K}\left(\mathrm{KNO}_{3}\right)$, $2.45 \mathrm{~N}\left[\mathrm{KNO}_{3}, \mathrm{Ca}\left(\mathrm{NO}_{3}\right)_{2}\right.$, and $\left.\mathrm{NH}_{4} \mathrm{NO}_{3}\right], 0.5 \mathrm{Mg}\left(\mathrm{MgSO}_{4}\right), 0.5$ $\mathrm{Ca}\left[\mathrm{Ca}\left(\mathrm{NO}_{3}\right)_{2}\right], 0.5 \mathrm{P}\left(\mathrm{KH}_{2} \mathrm{PO}_{4}\right)$, and $0.1 \mathrm{Si}\left(\mathrm{K}_{2} \mathrm{SiO}_{3}\right)$; micronutrients $(\mu \mathrm{M}) 5 \mathrm{Mn}\left(\mathrm{MnSO}_{4}\right), 0.08 \mathrm{Mo}\left[\left(\mathrm{NH}_{4}\right)_{6} \mathrm{Mo}_{7} \mathrm{O}_{24}\right], 0.5$ $\mathrm{Zn}\left(\mathrm{ZnSO}_{4}\right), 30 \mathrm{~B}\left(\mathrm{H}_{3} \mathrm{BO}_{3}\right), 0.12 \mathrm{Cu}\left(\mathrm{CuSO}_{4}\right)$, and $50 \mathrm{Fe}(\mathrm{Fe}-$ EDTA). The $\mathrm{pH}$ was adjusted and maintained at a value of 5.6. Before sowing, the racks with tubes were floated in a tray of nutrient solution. Arabidopsis ecotype Sf-1 seeds were suspended in the same nutrient solution described above and were loaded individually with a micropipette onto the top of the foam-filled seed holders. Sf-1 is an ecotype of arabidopsis that is originally from San Feliu, Spain. The seeds were obtained from the Ohio State Arabidopsis Biological Resource Center. Sf-1 is very similar to the standard ecotype, Col-0, in its physiology and morphology.

After sowing, the tray with seed holders was covered with aluminum foil and was incubated at $4{ }^{\circ} \mathrm{C}$ for $2 \mathrm{~d}$ to synchronize germination. Afterward, the tray was moved to a growth chamber maintained at $20{ }^{\circ} \mathrm{C}$ and a relative humidity of $70 \%$ under a 16-h photoperiod. Photosynthetic photon flux was set at $100 \mu \mathrm{mol} \cdot \mathrm{m}^{-2} \cdot \mathrm{s}^{-1}$. Nineteen days after sowing, plants were transferred into 4.5 -L opaque circular $(20 \mathrm{~cm}$ i.d. $\times 16.5 \mathrm{~cm}$ in height) plastic containers (12 plants per container) and were grown with continued aeration in a growth chamber. Nutrient solutions were replaced weekly. Thirty-five days after sowing (16 d after transfer), plants were treated with additional $\mathrm{Cu}$ and $\mathrm{Si}$. Four treatment regimes were examined: control [CK $(0.12$ $\mu \mathrm{M} \mathrm{Cu}$ and $0.10 \mathrm{~mm} \mathrm{Si})]$, elevated Si $(0.12 \mu \mathrm{M} \mathrm{Cu}$ and $1.5 \mathrm{~mm}$ $\mathrm{Si})$, elevated $\mathrm{Cu}(30 \mu \mathrm{M} \mathrm{Cu}$ and $0.10 \mathrm{~mm} \mathrm{Si})$, and elevated $\mathrm{Cu}$ and $\mathrm{Si}[\mathrm{Cu}+\mathrm{Si}(30 \mu \mathrm{M} \mathrm{Cu}$ and $1.5 \mathrm{~mm} \mathrm{Si})]$ with four replications (one replication consists of one hydroponic container). Arabidopsis growth experiments were repeated five times. The planting dates for these experiments varied from 15 Nov. 2006 to 25 June 2007, and the harvesting dates varied from 28 Dec. 2006 to 6 Aug. 2007.

After $3 \mathrm{~d}$ of treatment, shoots and roots were harvested, rinsed with distilled water, blotted dry, and fresh weight was determined. In the initial arabidopsis growth experiments, tissue was dried in a forced air oven at $55^{\circ} \mathrm{C}$ for $3 \mathrm{~d}$ and was used for tissue analysis. In the remainder of the arabidopsis growth experiments, the fresh tissue was immediately frozen in liquid nitrogen and stored at $-80{ }^{\circ} \mathrm{C}$ for subsequent use. Average and standard deviations for fresh weight and for all other data reported below were determined using Excel (Office 2003; Microsoft, Redmond, WA), which calculates these values as described in Neter et al. (1996).

Elemental analysis. Dried tissue was ground separately in a stainless steel mill to pass through a 1-mm (20-mesh) screen, and $0.15 \mathrm{~g}$ was digested in a microwave digester (MARS Express II; CEM Corp., Matthews, NC) using a modified EPA method [EPA method 3051 (Nelson, 1988): $\mathrm{HNO}_{3}$ digestion at
$200{ }^{\circ} \mathrm{C}$ with an additional peroxide digestion step]. Total nutrient concentrations for $\mathrm{P}, \mathrm{K}, \mathrm{Ca}, \mathrm{S}, \mathrm{Mg}, \mathrm{B}, \mathrm{Cu}, \mathrm{Fe}, \mathrm{Mn}$, and $\mathrm{Zn}$ were determined by inductively coupled plasma optical emission spectroscopy (model IRIS Intrepid II; Thermo Fisher Scientific, Waltham, MA). A quality control was run every 10 samples and if any element was determined to be more than $10 \%$ higher or lower than the standard value, the instrument was recalibrated. Tomato (Solanum lycopersicum L.) standards [National Institute of Standards and Technology (NIST, Gaithersburg, MD) reference material 1573 (Sharpless and Gill, 2000)] were compared every 20 samples and tomato and spinach (Spinacia oleracea L.) standards [NIST reference material 1570a (Sharpless and Gill, 2000)] were compared every 40 samples. Total $\mathrm{N}$ was analyzed with a total carbonhydrogen-nitrogen analyzer (model 2400; Perkin-Elmer, Waltham, MA).

Total Si concentration was quantified according to Frantz et al. (2008). Briefly, $0.15 \mathrm{~g}$ of dried, ground sample was mixed with $3.0 \mathrm{~mL}$ of $7.5 \mathrm{M} \mathrm{KOH}$ in a $55-\mathrm{mL}$ Teflon vessel. The solution was heated in a microwave by increasing the temperature to $200{ }^{\circ} \mathrm{C}$ over a period of $15 \mathrm{~min}$, and the solution was then held at that temperature for an additional $15 \mathrm{~min}$. After the digested material cooled to room temperature, $2 \mathrm{~mL}$ of $30 \%$ $\mathrm{H}_{2} \mathrm{O}_{2}$ was added. The temperature of the samples was increased to $200{ }^{\circ} \mathrm{C}$ over $15 \mathrm{~min}$ and was held at $200{ }^{\circ} \mathrm{C}$ for an additional $5 \mathrm{~min}$. After cooling, the solution was filtered (Whatman No. 2), and $1 \mathrm{~mL}$ of the filtrate was diluted with $9 \mathrm{~mL}$ of deionized water (18 megaohm purity) and was analyzed by inductively coupled plasma optical emission spectroscopy. A quality control was run every 10 samples, and if $\mathrm{Si}$ was determined to be more than $10 \%$ higher or lower than the standard value, the instrument was recalibrated with a blank and a highstandard solution of $9.985 \mathrm{mg} \cdot \mathrm{L}^{-1}$ with a background matrix of $0.75 \mathrm{M} \mathrm{KOH}$. Every 20 samples, a laboratory-grown standard of rice (Oryza sativa L.) straw containing $9.6 \mathrm{~g} \cdot \mathrm{kg}^{-1}$ (dry weight) was analyzed as a reference (L. Datnoff, personal communication).

Phenylalanine ammonia lyase [PAL (EC 4.3.1.5)] enzyme ASSAYS. PAL activity was measured by the method described in Liang et al. (2005) with some modifications. Briefly, $1.0 \mathrm{~g}$ of fresh leaf segments were homogenized in liquid nitrogen in $5 \mathrm{~mL}$ of $50 \mathrm{~mm}$ borate buffer $(\mathrm{pH} 8.8)$ containing $5.0 \mathrm{~mm}$ thioalcohol and $1 \mathrm{~mm}$ EDTA. The homogenate was thawed and centrifuged at $9000 g_{\mathrm{n}}$ for $25 \mathrm{~min}$ at $4{ }^{\circ} \mathrm{C}$. A reaction mixture containing $3.8 \mathrm{~mL}$ of $50 \mathrm{~mm}$ borate buffer, $\mathrm{pH} 8.8$, and $1.0 \mathrm{~mL}$ of $20 \mathrm{~mm}$ phenylalanine was added to $0.2 \mathrm{~mL}$ of the crude enzyme extract. After incubating at $60{ }^{\circ} \mathrm{C}$ for $60 \mathrm{~min}$, the reaction was ended by adding $1 \mathrm{~mL}$ of $600 \mathrm{~mm} \mathrm{HCl}$. Absorbance of the colored trans-cinnamate was recorded at $290 \mathrm{~nm}$. One unit of enzyme activity was defined as the absorbance increase by $0.01 \mathrm{~A}_{290}$ units per hour. Enzyme activity was expressed as units per milligram of protein. The soluble protein concentrations of the extracts were measured by the method of Bradford (1976) using bovine serum albumin as a standard.

GENE EXPRESSION ANALYSIS BY QUANTITATIVE REAL-TIME REVERSE TRANSCRIPTASE-POLYMERASE CHAIN REACTION (RTPCR). Total RNA was isolated from arabidopsis tissues with the PureLink ${ }^{\mathrm{TM}}$ Plant RNA Purification Reagent (Invitrogen ${ }^{\mathrm{TM}}$, Carlsbad, CA) according to the manufacturer's specifications. The samples were digested with TURBO DNase (TURBO DNA-free ${ }^{\mathrm{TM}} \mathrm{kit}$; Ambion, Austin, TX), according to the 
manufacturer's specifications, to remove contaminating DNA, and the RNA was quantified by ultraviolet spectrophotometry. The integrity of RNA was visually assessed by formaldehydeagarose gel (1\%) electrophoresis.

Two micrograms of total RNA, isolated from arabidopsis roots and shoots, was first converted to cDNA by RT (Invitrogen) using random hexamer primers for arabidopsis genes: multi-copper oxidase type I family protein (MCO) and esterase lipase thioesterase family protein $(E L T)$. For the arabidopsis COPT1 and HMA5 genes, total root RNA was converted to cDNA by SuperScriptII reverse transcriptase (Invitrogen) using anchored oligo $(\mathrm{dT})_{20}$ (Roche Applied Science, Indianapolis) primers according to the manufacturer's specifications.

Gene-specific primers (Table 1) were designed based on arabidopsis cDNA sequences obtained from TAIR (GarciaHernandez et al., 2002), which were imported into PrimerSelect software (DNASTAR, Madison, WI). At least one primer of each pair was designed to span an exon-exon junction. An exonexon junction is the site where two exons are joined in the mature RNA but which are separated by an intron in the genomic DNA. Hence, the PCR products obtained in this analysis are only from an mRNA template and not from DNA because the primer binding site is interrupted by an intron in the genome. Actin was used as an internal control.

PCR were performed in 96-well plates (TempPlate, Scientific, Ocala, FL) using iQ ${ }^{\mathrm{TM}} \mathrm{SYBR}{ }^{\circledR}$ Green Supermix (Bio-Rad, Hercules, CA) to monitor dsDNA synthesis. Reactions contained $12.5 \mu \mathrm{L}$ of $2 \times$ SYBR Green Supermix, $2 \mu \mathrm{L}$ of cDNA, and $400 \mathrm{~nm}$ each of gene-specific primer in a final volume of $25 \mu \mathrm{L}$. A master mix, excluding cDNA, was prepared before dispensing the reaction mixture into individual wells of 96-well PCR plates to reduce pipetting errors. All RT-PCR experiments were performed multiple times. The cDNA products generated from the ELT and $M C O$ genes were from two biological replications done in triplicate, while those amplified from the COPT1 and HMA5 genes were from three biological replicates performed in duplicate. Reactions were performed using the iCycler Real-time PCR Detection System (Bio-Rad) with the two-step amplification plus melting curve protocol. The reaction conditions consisted of an initial denaturation step at $95{ }^{\circ} \mathrm{C}$ for $3 \mathrm{~min}$, followed by 40 cycles of: $94{ }^{\circ} \mathrm{C}$ for $30 \mathrm{~s}$ (denaturation), $57{ }^{\circ} \mathrm{C}$ (ELT, COPT1, and HMA5) or $58{ }^{\circ} \mathrm{C}$ (MCO) for $30 \mathrm{~s}$ (annealing) and $72{ }^{\circ} \mathrm{C}$ for $30 \mathrm{~s}$ (elongation). Actin primers were used in the same 96-well plates and were simultaneously amplified along with the other genes by the same program, to serve as an internal control. The values for threshold cycle $\left(\mathrm{C}_{\mathrm{t}}\right)$ determination were generated automatically by iCycler software. The parameter $\mathrm{C}_{\mathrm{t}}$ (threshold cycle) is defined as the amplification cycle number at which the fluorescence, due to the formation of a PCR product, passes a fixed threshold. ELT, MCO, COPT1, and HMA5 expression levels were reported as fold change $\left(2^{-\Delta \mathrm{Ct} \text { (treated-calibrator) }}\right)$ in which treated $C_{t}$ values were normalized with the corresponding $C_{t}$ values of actin; the calibrator $C_{t}$ values were the normalized control $\mathrm{C}_{\mathrm{t}}$ values. Calculations were performed as described by Dorak (2006). The fold change and the standard deviation were calculated with Excel.

\section{Results and Discussion}

SOLUbLe SI AND FOLIAR AND ROOT DAMAGE INDUCED BY EXCESS Cu. Arabidopsis appeared healthy and showed no obvious stress symptoms when grown under control levels of $\mathrm{Cu}(0.12$ $\mu \mathrm{M})$ and $\mathrm{Si}(0.10 \mathrm{~mm})$ (Fig. 1A). Leaf tissue nutrient concentrations indicated no deficiencies or toxicities based on comparisons of recommendations for related species [Brassica juncea (L.) Czern., Brassica oleracea L., Brassica perviridis L.H. Bailey, and Brassica rapa L.] (Table 2; Mills and Jones, 1996) with the possible exception of $\mathrm{N}$ and $\mathrm{Mn}$, which were slightly above the highest reported value for $\mathrm{N}$ and $\mathrm{Mn}$ in these species. Plants also grew well under elevated $(1.5 \mathrm{~mm}) \mathrm{Si}$ conditions, and tissue nutrient concentrations for everything except $\mathrm{Si}$ were not different from the controls.

In contrast, arabidopsis plants grown under elevated $\mathrm{Cu}$ conditions $(30 \mu \mathrm{M})$ showed reduced growth and chlorosis starting at the tips of older leaves (Fig. 1, A and B). Occasionally, the older leaves became completely chlorotic. The plant chloroplast is particularly sensitive to $\mathrm{Cu}$ toxicity (Abdel-Ghany et al., 2005; Shikanai et al., 2003). Moreover, $\mathrm{Cu}$ is a cofactor in the ethylene-signaling pathway (Hirayama et al., 1999). Excess Cu supply could intensify ethylene responses and hasten aging, which would explain leaf chlorosis as well as the reduction of shoot fresh weight (Fig. 1B) (see below).

The tissue from plants grown under elevated $\mathrm{Cu}$ showed significant differences in concentrations for many nutrients (Table 2): the macronutrient ( $, \mathrm{P}, \mathrm{K}, \mathrm{Ca}, \mathrm{S}$, and $\mathrm{Mg}$ ) concentrations were significantly different from the control and the elevated Si treatment concentrations; the micronutrients $\mathrm{B}, \mathrm{Cu}, \mathrm{Mn}$, and $\mathrm{Zn}$ were also significantly different from the control and the elevated $\mathrm{Si}$ treatments, with $\mathrm{Cu}$ concentrations being significantly elevated above those treatments. These changes in tissue nutrient concentrations are indicative of

Table 1. Primers used in these experiments to examine the gene expression of multi-copper oxidase type I family protein (MCO), esterase lipase thioesterase family protein (ELT), copper transporter 1 (COPT1), heavy metal ATPase 5 (HMA5), and actin.

\begin{tabular}{|c|c|c|c|}
\hline Primer name & $\begin{array}{c}\text { Sequence }\left(5^{\prime}-3^{\prime}\right) \text {; } \\
\text { (forward, upper; reverse, lower) }\end{array}$ & $\begin{array}{l}\text { Product size } \\
\text { (bp) }\end{array}$ & $\begin{array}{c}\text { Locus no. } \\
\text { (Garcia-Hernandez, et al., 2002) }\end{array}$ \\
\hline \multirow[t]{2}{*}{$\overline{M C O}$} & GCTCGAGCTATCAGGACCAACCTT & 103 & At1g21860 \\
\hline & CAAGTCTGATCGTTCGGGTGATGT & & \\
\hline \multirow[t]{2}{*}{$E L T$} & CCCCACAGACTAGCTGGAGCAGT & 147 & At5g22460 \\
\hline & CCACGGAACATAATGAGCCACTTT & & \\
\hline \multirow[t]{2}{*}{ COPT1 } & CGAAGGAGGAGGACATCACCACAT & 148 & At5g59030 \\
\hline & GACGGCGAGAAAGAAGACAAAGAT & & \\
\hline \multirow[t]{2}{*}{$H M A 5$} & CGCTGGATCTGTTGAAAAGGCTATCA & 116 & At1g63440 \\
\hline & TCTCCACATCGACAGAGTTAGGGTA & & \\
\hline \multirow[t]{2}{*}{ Actin } & CAACCGGTATTGTGCTGGATTCTGG & 99 & At3g18780 \\
\hline & GCAAGGTCAAGACGGAGGATGG & & \\
\hline
\end{tabular}




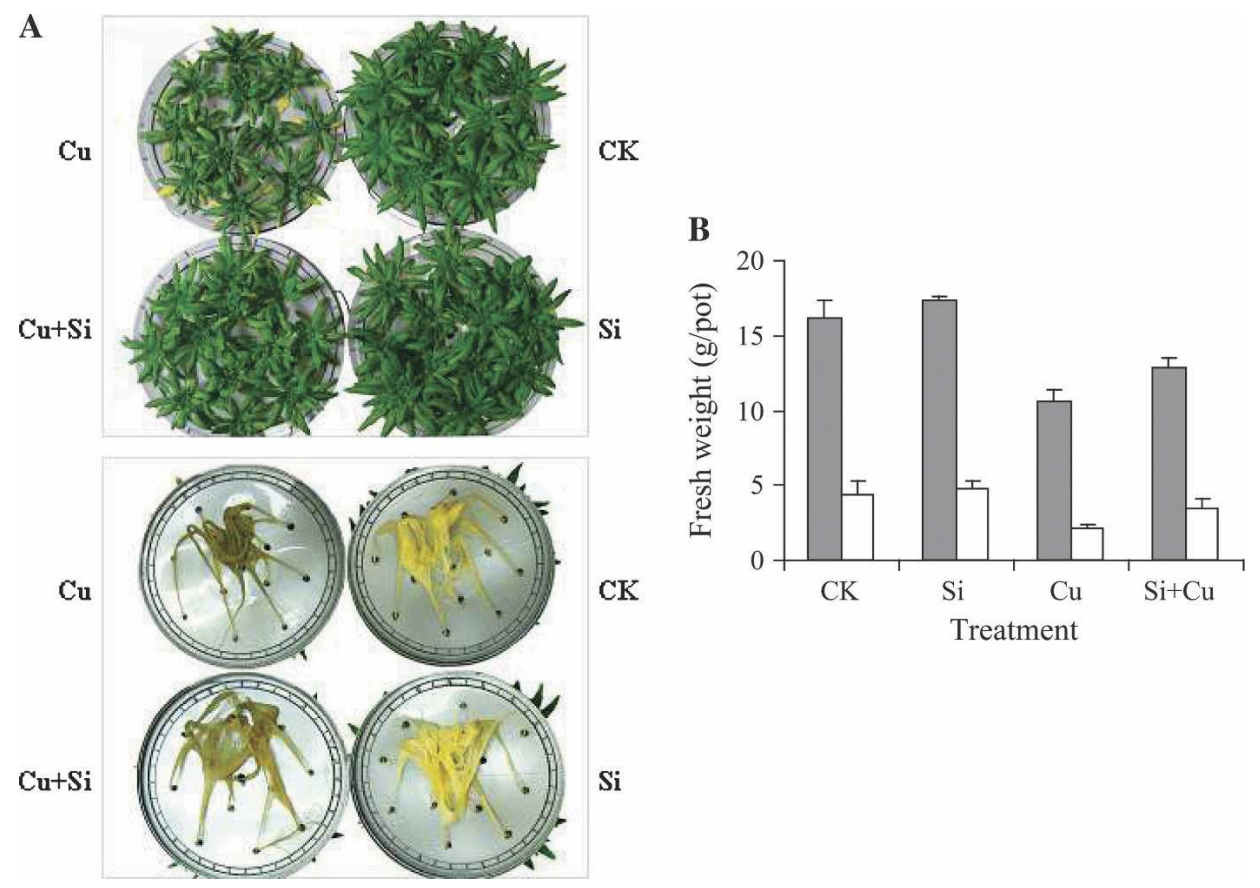

Fig. 1. Responses of arabidopsis shoots and roots to elevated $\mathrm{Si}$ and $\mathrm{Cu}$. Arabidopsis plants were treated with $\mathrm{Si}$ and $\mathrm{Cu}$ and analyzed after $3 \mathrm{~d}$. The treatments were: control [CK $(0.12 \mu \mathrm{M} \mathrm{Cu}+0.10 \mathrm{~mm} \mathrm{Si})]$, elevated $\mathrm{Si}[\mathrm{Si}(0.12 \mu \mathrm{M}$ $\mathrm{Cu}+1.5 \mathrm{~mm} \mathrm{Si})]$, elevated $\mathrm{Cu}[\mathrm{Cu}(30 \mu \mathrm{M} \mathrm{Cu}+0.10 \mathrm{~mm} \mathrm{Si})]$, and elevated $\mathrm{Cu}$ and $\mathrm{Si}[\mathrm{Cu}+\mathrm{Si}(30 \mu \mathrm{M} \mathrm{Cu}+1.5$ $\mathrm{mm} \mathrm{Si}$ )]. (A) Arabidopsis shoot (upper) and root (lower) growth under different conditions; (B) changes in shoot (shaded) and root (white) fresh weight under different conditions. Error bars indicate SD $(n=4)$.

whitish-yellow (Fig. 1A). In contrast, the root weight of plants grown under elevated $\mathrm{Cu}$ was less and the roots were dark brown, indicating the presence of phenolics or deposition of metal oxides on the root surface. Roots grown under elevated $\mathrm{Cu}$ and supplemented with Si appeared light brown, but were more vigorous than plants grown under elevated $\mathrm{Cu}$ without supplemental Si. These data were also reflected in the fresh weight measurements (Fig. 1B). Hence, Si partially alleviated $\mathrm{Cu}$ stress in roots, permitting better growth.

When grown in elevated $\mathrm{Cu}$, arabidopsis shoots had elevated total $\mathrm{Cu}$ levels whether Si concentration was elevated or not (Table $2)$. The improved growth and decrease in visual stress symptoms when additional $\mathrm{Si}$ is present suggest that under elevated $\mathrm{Cu}$ conditions, $\mathrm{Si}$ is influencing the distribution or bioavailability of $\mathrm{Cu}$ within leaves. This is analogous to the reported effects of elevated $\mathrm{Si}$ on the distribution of $\mathrm{Mn}$; soluble $\mathrm{Si}$ reduced $\mathrm{Mn}$ toxicity in several plant

general stress but do not fall outside the "normal" ranges for the recommendations for Brassica species (Mills and Jones, 1996).

Elevated Si treatment alleviated the reduction of shoot and root fresh weight caused by elevated $\mathrm{Cu}$ alone (Fig. 1B) and reduced leaf chlorosis caused by $\mathrm{Cu}$ toxicity. Tissue nutrient concentrations recovered nearly to control levels for all nutrients, with the exception of $\mathrm{Cu}$ concentrations; supplemental $\mathrm{Si}$ did not change total $\mathrm{Cu}$ concentrations in the leaf tissue.

Arabidopsis grown under control hydroponic and elevated Si conditions showed robust root growth and roots appeared species (Horst and Marscher, 1978; Iwasaki et al., 2002a, 2002b, 2002c; Rogalla and Römheld, 2002a, 2002b) not because of a reduction in Mn uptake or translocation (Horst and Marschner, 1978), but because the distribution of Mn throughout the leaves was more diffuse. As a result, toxic levels of Mn did not accumulate in particular groups of cells. More recent studies attributed these protective effects to the deposition of Si in plant cell walls, which provided additional binding sites for metals and thus reduced their apoplastic bypass flow (Ma and Yamaji, 2006). Thus, in our experiments, the concentration of free $\mathrm{Cu}$ could be suppressed as a consequence of the

Table 2. Arabidopsis leaf tissue nutrient concentrations. Arabidopsis plants were treated with $\mathrm{Si}$ and $\mathrm{Cu}$ and harvested after $3 \mathrm{~d}$. The treatments were: control [CK $(0.12 \mu \mathrm{M} \mathrm{Cu}+0.10 \mathrm{~mm} \mathrm{Si})]$, elevated Si [Si $(0.12 \mu \mathrm{M} \mathrm{Cu}+1.5 \mathrm{~mm} \mathrm{Si})]$, elevated $\mathrm{Cu}[\mathrm{Cu}(30 \mu \mathrm{M} \mathrm{Cu}+0.10 \mathrm{~mm} \mathrm{Si})]$, elevated $\mathrm{Cu}$ and $\mathrm{Si}[\mathrm{Cu}+\mathrm{Si}(30 \mu \mathrm{M} \mathrm{Cu}+1.5 \mathrm{~mm} \mathrm{Si})]$. Values are averages of four replicates with each replicate consisting of 12 plants. Data were analyzed using a two-way analysis of variance.

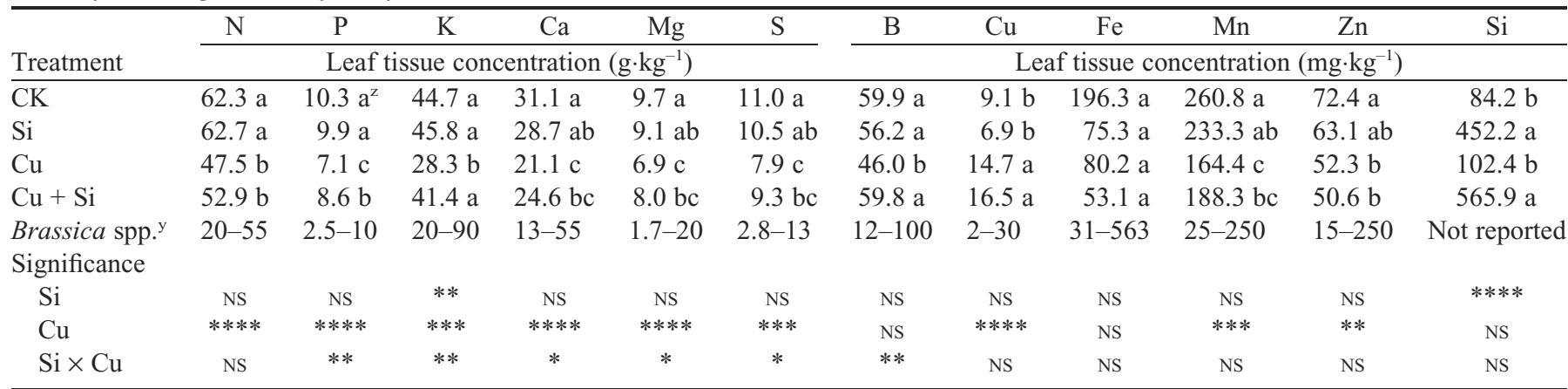

${ }^{\mathrm{y}}$ Range of values taken from Mills and Jones (1996) for the highest and lowest surveyed values from B. juncea, B. oleracea, B. perviridis, and B. rapa.

${ }^{z}$ Means within columns followed by the same letter are not significantly different $(\alpha=0.05)$ based on Tukey's pairwise comparison.

ns, *, **, *** Nonsignificant or significant at $P \leq 0.05,0.01,0.001$, or 0.0001 , respectively. 
formation of $\mathrm{Si}$ cross-linked binding pools for $\mathrm{Cu}$ in the cell walls, analogous to the studies on Mn (Iwasaki et al., 2002b; Rogalla and Römheld, 2002b). However, not all cases of Si alleviation of Mn toxicity are due to sequestration of Mn within the cell wall. For example, Iwasaki et al, (2002c) reported that in cowpea [Vigna unguiculata (L.) Walp.], the sensitivity of Mn-toxicity symptoms was not correlated with the Mn concentration within the apoplastic solution, but was highly correlated with the water-soluble Si in the apoplast.

Si AND PAL aCTIVITy. An almost ubiquitous feature of plant response to incompatible environmental conditions is the activation of phenylpropanoid biosynthetic pathway in which PAL catalyzes the first committed step (Schuster and Rétey, 1995). The downstream products of PAL activity in plants have a beneficial effect on host responses to pathogen invasion, wounding reactions, chilling susceptibility, and adverse environmental stress. In arabidopsis, PAL activity was induced by excess $\mathrm{Cu}$ in roots and shoots when compared with $\mathrm{CK}$ - and $\mathrm{Si}-$ treated plants (Fig. 2). Even though PAL activity was elevated in the shoots of arabidopsis grown in excess $\mathrm{Cu}$, it was reduced to near-control levels in arabidopsis grown in excess $\mathrm{Cu}+\mathrm{Si}$ (Fig. 2).

The decrease in PAL activity in the shoots of Si-supplemented plants grown in excess $\mathrm{Cu}$ suggests that these plants are not experiencing the same level of stress as plants grown in elevated $\mathrm{Cu}$ alone. The mechanism for this reduced stress may be from the formation of Si-phenol complexes (Rogalla and Römeheld, 2002c) and their subsequent cross linkage with wall polymers. Si-mediated extension of wall-binding sites for $\mathrm{Cu}$ could buffer the free apoplastic $\mathrm{Cu}$, analogous to the findings of Maksimovic et al. (2007). Si addition has been reported to decrease the concentration of plant-borne substrates of antioxidative enzymes, such as ferulic acid and coniferyl alcohol under $100 \mu \mathrm{M}$ Mn (Maksimovic et al., 2007). Thus, the decreased levels of these phenolic compounds may downregulate PAL activity, as a feedback adjustment. This would result in fewer substrates for plant oxidative enzymes and a reduction of oxidative stress.

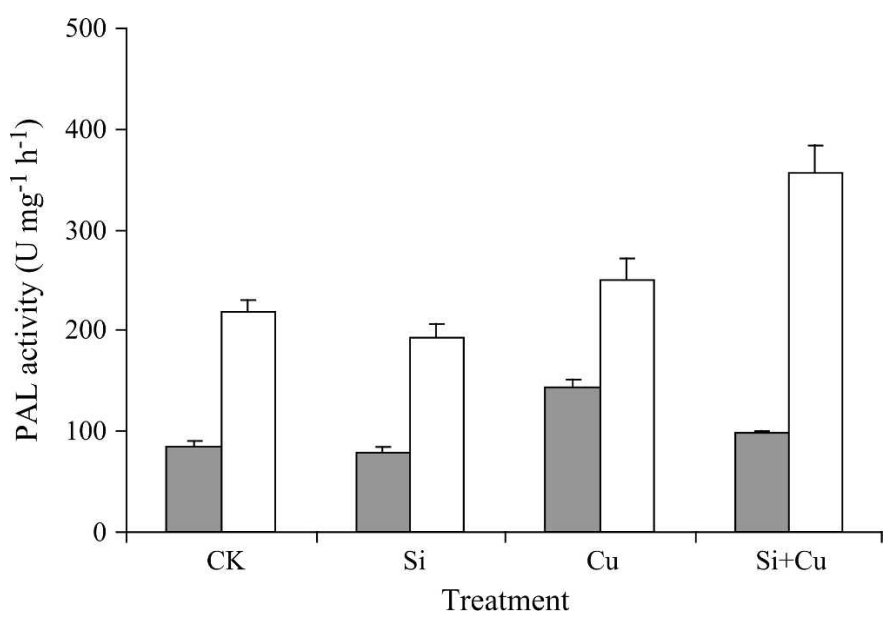

Fig. 2. Effects of $\mathrm{Si}$ and $\mathrm{Cu}$ treatments on arabidopsis phenylalanine ammonialyase (PAL) activity in shoots (shaded) and roots (white). Plants were treated for $3 \mathrm{~d}$ under hydroponic conditions. The treatments were: control [CK $(0.12$ $\mu \mathrm{M} \mathrm{Cu}+0.10 \mathrm{~mm} \mathrm{Si})]$, elevated $\mathrm{Si}[\mathrm{Si}(0.12 \mu \mathrm{M} \mathrm{Cu}+1.5 \mathrm{~mm} \mathrm{Si})]$, elevated $\mathrm{Cu}$ $[\mathrm{Cu}(30 \mu \mathrm{M} \mathrm{Cu}+0.10 \mathrm{~mm} \mathrm{Si})]$, and elevated $\mathrm{Si}$ and $\mathrm{Cu}[\mathrm{Si}+\mathrm{Cu}(1.5 \mathrm{~mm} \mathrm{Si}+$ $30 \mu \mathrm{M} \mathrm{Cu})$ ]. PAL activity is expressed as units per milligram of total protein per hour. Error bars indicate SD $(n=12)$.
The situation was different in roots. PAL activity in roots was higher under elevated $\mathrm{Cu}$ conditions than in control or elevated Si treatments, but the PAL activity of arabidopsis grown under elevated $\mathrm{Si}$ and $\mathrm{Cu}$ was greater than with either nutrient alone (Fig. 2). One possible explanation for this is that Si helped stimulate accumulation of polymerized phenolics in roots by stimulating PAL activity (Cherif et al., 1992) to resist toxicity by direct exposure to $\mathrm{Cu}$. As mentioned above for shoots, $\mathrm{Si}$ addition to roots could result in the formation of $\mathrm{Si}$ phenolic complexes, thereby reducing the concentration of free phenols (Rogalla and Römeheld, 2002c). The sequestration of phenolic compounds by Si would reduce the available substrates for oxidative browning enzymes involved in the expression of $\mathrm{Cu}$-toxicity symptoms. Therefore, although PAL activity was elevated by $\mathrm{Si}$ supplementation at high $\mathrm{Cu}$ concentration, the roots were not as brown as with elevated $\mathrm{Cu}$ alone (Fig. 1A). However, $\mathrm{Si}$ is mainly deposited in shoots (Yoshida, 1965). Hence, the role of Si in roots might be to stimulate plant defenses to protect the roots against $\mathrm{Cu}$ toxicity, but it may not function in the same way as in shoots. Roots possess an endodermis, which regulates nutrient uptake into the vascular system, while most shoots do not. Therefore, the deposition of $\mathrm{Si}$ in the endodermal layer could act as a natural barrier to shoot $\mathrm{Cu}$ uptake, as proposed for $\mathrm{Cd}$ (Kirkham, 2006). If $\mathrm{Cu}$ uptake into the vascular system is blocked, this would result in accumulation of $\mathrm{Cu}$ in epidermal and cortical cells, inducing stress responses such as increased PAL activity.

Si AND THE EXPRESSION OF MCO AND ELT. To investigate the beneficial effects of $\mathrm{Si}$ on $\mathrm{Cu}$ toxicity at the molecular level, we examined the expression of arabidopsis genes influenced by $\mathrm{Si}$. Si treatment alone is reported to affect the expression of two arabidopsis genes: multicopper oxidase ( $M C O$, At1g21860.1) and a particular esterase called ELT (At5g22460.1) (Fauteux et al., 2006). The Escherichia coli Escherich MCO gene product safeguards the periplasm and plasma membrane from $\mathrm{Cu}$-induced damage (Rensing and Grass, 2003). Perhaps $M C O$ plays a similar plasma membrane-stabilizing role in plants. Esterases (EC 3.1.1.x) represent a diverse group of hydrolases catalyzing the cleavage and formation of carboxyl ester bonds.

The pattern of expression in shoots and roots differed for these genes (Fig. 3). For example, Si caused a slight elevation of $M C O$ expression in shoots and had no effect in roots (Fig. 3, A and $\mathrm{B}$ ). In contrast, ELT expression was more variable in Sitreated shoots and was not different from the controls (Fig. 3C). However, the expression of ELT in Si-treated roots was elevated above that of the controls (Fig. 3D). Treatment with elevated $\mathrm{Cu}$ or elevated $\mathrm{Cu}$ along with elevated $\mathrm{Si}$ caused a decrease in $M C O$ expression in shoots when compared with controls (Fig. 3A). Interestingly, increased $\mathrm{Cu}$ caused an increase in $M C O$ expression in roots above that of the controls, although treatment with $\mathrm{Si}$ did not alter the level of expression (Fig. 3B). Thus, toxicity caused by excess $\mathrm{Cu}$ induced $M C O$ expression in roots, possibly to protect the plasma membranes of root cells regardless of whether $\mathrm{Si}$ was present or not. Compared with roots (that are directly exposed to excess $\mathrm{Cu}$ ), $\mathrm{Cu}$ stress in shoots was obviously much less (based on visual observation and PAL activities), and as a result, the expression pattern detected in shoots was not the same as in roots (Fig. 3A). Hence, elevated $\mathrm{Cu}$ appears to reduce $M C O$ expression in shoots, while elevating it in roots.

Contrary to $M C O, E L T$ expression in shoots and roots was increased by $30 \mu \mathrm{M} \mathrm{Cu}$ alone or in combination with elevated 

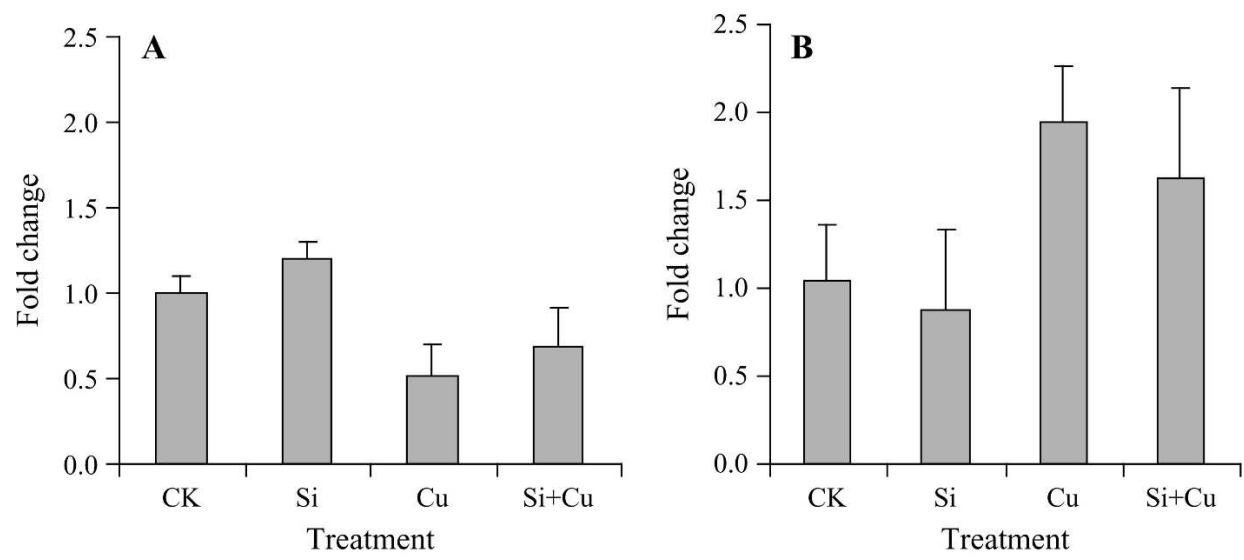

a role in the export of $\mathrm{Cu}$ from roots to shoots. HMA5 is induced by $\mathrm{Cu}$ (Andrés-Colás et al., 2006), and we observed this as well (Fig. 4B). Si has a suppressive effect on the expression of HMA5 in the presence of elevated and control levels of $\mathrm{Cu}$. In fact, treatment of arabidopsis with elevated $\mathrm{Si}$ and $\mathrm{Cu}$ decreased HMA5 expression to control levels in roots. Hence, $\mathrm{Si}$ reduced the expression of two $\mathrm{Cu}$ transporter genes in roots.

Taking these data together, we propose a potential model for $\mathrm{Si}$
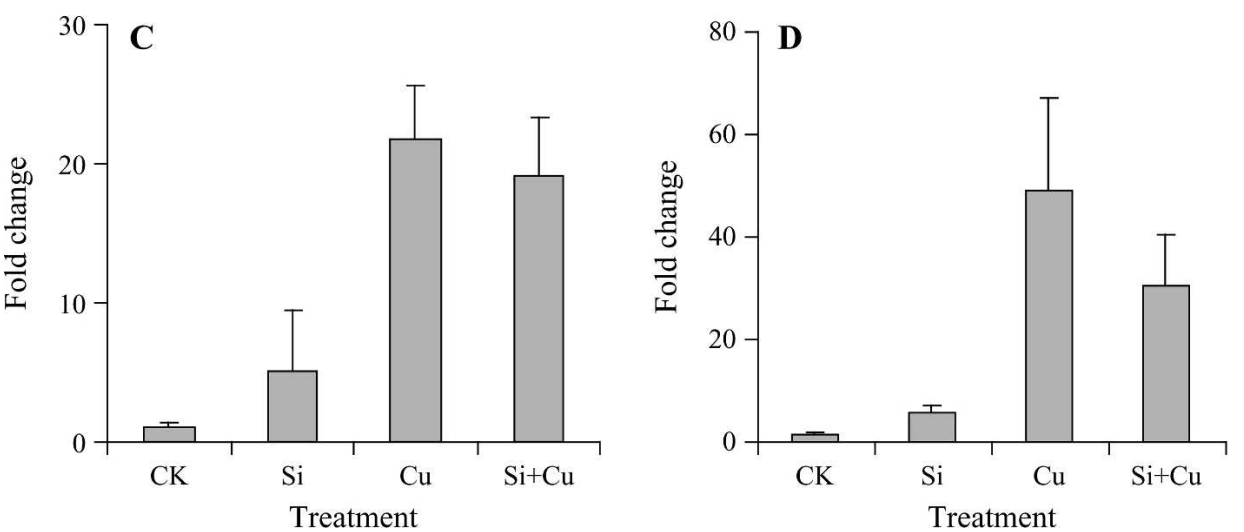
alleviation of $\mathrm{Cu}$ toxicity in arabidopsis. The levels of $\mathrm{Cu}$ entering the shoots grown under elevated $\mathrm{Cu}$ conditions cause leaf tissue to experience stress, resulting in increased PAL activity. The increase in PAL activity leads to elevated production of phenolic compounds that then bind to $\mathrm{Cu}$ and reduce its bioavailability. When Si is also elevated, we speculate that a portion of the $\mathrm{Si}$ taken up by the shoots is incorporated into the cell wall and provides additional $\mathrm{Cu}$-binding sites. In this way, the $\mathrm{Cu}$ bioavailability is decreased, reducing stress in shoots, with a subsequent decline in PAL activity. This would also explain why shoots show reduced stress, but still contain large amounts of total $\mathrm{Cu}$.

Under elevated $\mathrm{Cu}$ conditions,

Si. Thus, ELT expression was more strongly induced by $\mathrm{Cu}$ than by $\mathrm{Si}$ in roots and shoots. In contrast, elevated $\mathrm{Cu}$ reduced $M C O$ expression in shoots, while elevating it in roots.

Si AND THE EXPRESSION OF GENES INVOLVED IN CU TRANSPORT. Arabidopsis leaf $\mathrm{Cu}$ levels increased as $\mathrm{Cu}$ concentrations were elevated in the hydroponic solution. $\mathrm{Cu}$ uptake and transport relies on specific proteins. Therefore, we examined the expression of two genes involved in $\mathrm{Cu}$ transport: COPT1 and HMA5 (Birnbaum et al., 2003; Sancenón et al., 2003). Because both genes encode transporters that are located in root cells, expression of these genes was only examined in roots.

COPT1 encodes an arabidopsis plasma membrane transporter playing a key role in the uptake of $\mathrm{Cu}$ from the surrounding growth medium into roots (Kampfenkel et al., 1995). Plants exposed to elevated Si showed an increase in COPT1 expression when compared with controls (Fig. 4A). Arabidopsis exposed to elevated $\mathrm{Cu}$ levels showed an even greater increase in COPT1 expression, which has been reported previously (Sancenón et al., 2004). In contrast, when Si as well as $\mathrm{Cu}$ levels were elevated in the hydroponic solution, a reduction of COPTI expression compared with elevated $\mathrm{Cu}$ alone was observed.

The arabidopsis HMA5 gene encodes a heavy metal transport ATPase subunit (Andrés-Colás et al., 2006). HMA5 is primarily expressed in root pericycle cells and is thought to play the stress in roots causes an increase in PAL activity to produce secondary metabolites that bind to $\mathrm{Cu}$ and reduce its bioavailability. Our data show that PAL activity of roots is higher than in shoots, probably because roots are more directly exposed to higher levels of $\mathrm{Cu}$ than shoots. However, $\mathrm{Si}$ and $\mathrm{Cu}$ can bind to phenolic compounds and may compete for binding sites. Hence, more phenolic compounds would be needed and PAL activity would rise even higher in the plants treated with elevated $\mathrm{Si}$ and $\mathrm{Cu}$ than with elevated $\mathrm{Cu}$ alone. The increased phenolics in roots would give rise to the brown appearance in plants treated with elevated $\mathrm{Cu}$ or both elevated $\mathrm{Cu}$ and $\mathrm{Si}$. Alternatively, the color may be due to the deposition of a metal oxide on the root surface. Because the root cells may have multiple binding sites for $\mathrm{Cu}$ by $\mathrm{Si}$ and phenolic compounds, the amount of free $\mathrm{Cu}$ accessible to the apoplast would decrease. Because the COPT1 and HMA5 transporter genes are induced by $\mathrm{Cu}$, the reduction in bioavailable $\mathrm{Cu}$ to the roots due to its sequestration in the apoplast by $\mathrm{Si}$ and phenolic compounds or the deposition of a metal oxide would cause the expression of these genes to decline. The reduction in expression induced by $\mathrm{Si}$ does not lead to lower leaf $\mathrm{Cu}$ levels. This may be because the reduction in COPT1 and HMA5 expression may occur late in the response to high $\mathrm{Cu}$. This would lead to further protection of roots against $\mathrm{Cu}$, while the $\mathrm{Cu}$ already present within the shoot would be retained. 

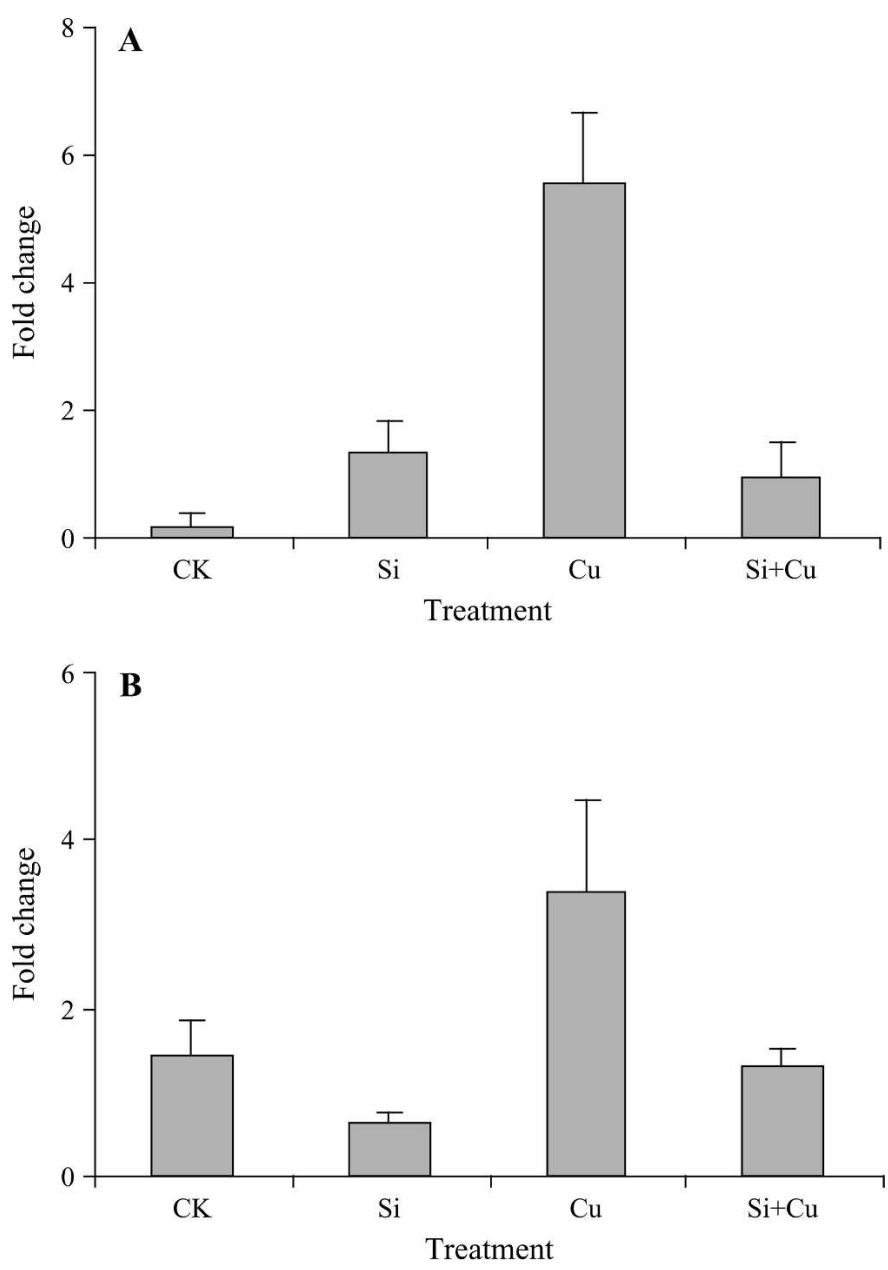

Fig. 4. Expression of copper transporter 1 (COPT1; A) and heavy metal ATPase 5 (HMA5; B) genes in arabidopsis roots after treatment for $3 \mathrm{~d}$ with various combinations of $\mathrm{Si}$ and $\mathrm{Cu}$ under hydroponic conditions. The treatments were: control [CK $(0.12 \mu \mathrm{M} \mathrm{Cu}+0.10 \mathrm{~mm} \mathrm{Si})]$, elevated Si $[\mathrm{Si}(0.12 \mu \mathrm{M} \mathrm{Cu}+1.5 \mathrm{~mm}$ $\mathrm{Si})]$, elevated $\mathrm{Cu}[\mathrm{Cu}(30 \mu \mathrm{M} \mathrm{Cu}+0.10 \mathrm{~mm} \mathrm{Si})]$, and elevated $\mathrm{Si}$ and $\mathrm{Cu}[\mathrm{Si}+$ $\mathrm{Cu}(1.5 \mathrm{~mm} \mathrm{Si}+30 \mu \mathrm{M} \mathrm{Cu})]$. Actin was used to correct for variations in RNA levels. Averages are shown with error bars indicating SD $(\mathrm{n}=12)$.

\section{Literature Cited}

Abdel-Ghany, S.E., P. Müller-Moulé, K.K. Niyogi, M. Pilon, and T. Shikanai. 2005. Two P-type ATPase are required for $\mathrm{Cu}$ delivery in Arabidopsis thaliana chloroplasts. Plant Cell 17:1233-1251.

Andrés-Colás, N., V. Sancenón, S. Rodríguez-Navarro, S. Mayo, D.J. Thiele, J.R. Ecker, S. Puig, and L. Peñarrubia. 2006. The Arabidopsis heavy metal P-type ATPase HMA5 interacts with metallochaperones and functions in $\mathrm{Cu}$ detoxification of roots. Plant J. 45:225-236.

Birnbaum, K., D.E. Shasha, J.Y. Wang, J.W. Jung, G.M. Lambert, D.W. Galbraith, and P.N. Benfey. 2003. A gene expression map of the Arabidopsis root. Science 302:1956-1960.

Bradford, M.M. 1976. A rapid and sensitive method for the quantitation of microgram quantities of protein utilizing the principle of protein-dye binding. Anal. Biochem. 72:248-254.

Cherif, M., N. Benhamou, J.G. Menzies, and R.R. Bélanger. 1992. Silicon-induced resistance in cucumber plants against Pythium ultimum. Physiol. Mol. Plant Pathol. 41:411-425.

Datnoff, L.E., W.H. Elmer, and D.M. Huber. 2007. Mineral nutrition and plant disease. APS Press, St. Paul, MN.

Dorak, M.T. 2006. Real-time PCR. Taylor and Francis, New York.
Epstein, E. 1994. The anomaly of Si in plant biology. Proc. Natl. Acad. Sci. USA 91:11-17.

Epstein, E. 1999. Silicon. Annu. Rev. Plant Physiol. Plant Mol. Biol. 50:641-664.

Epstein, E. and J.A. Bloom. 2005. Mineral nutrition of plants: Principles and perspective. 2nd ed. Sinauer, Sunderland, MA.

Fauteux, F., F. Chain, F. Belzile, J.G. Menzies, and R.R. Bélanger. 2006. The protective role of $\mathrm{Si}$ in the Arabidopsis-powdery mildew pathosystem. Proc. Natl. Acad. Sci. USA 103:17554-17559.

Fox, T.C. and M.L. Guerinot. 1998. Molecular biology of cation transport in plants. Annu. Rev. Plant Physiol. Plant Mol. Biol. 49:669-696.

Frantz, J.M., J.C. Locke, L. Datnoff, M. Omer, A. Widrig, D. Sturtz, L. Horst, and C.R. Krause. 2008. Detection, distribution, and quantification of $\mathrm{Si}$ in floricultural crops utilizing three distinct analytical methods. Commun. Soil Sci. Plant Anal. (in press).

Garcia-Hernandez, M., T.Z. Berardini, G. Chen, D. Crist, A. Doyle, E. Huala, E. Knee, M. Lambrecht, N. Miller, L.A. Mueller, S. Mundodi, L. Reiser, S.Y. Rhee, R. Scholl, J. Tacklind, D.C. Weems, Y. Wu, I. $\mathrm{Xu}$, D. Yoo, J. Yoon, and P. Zhang. 2002. TAIR: A resource for integrated Arabidopsis data. Funct. Integr. Genomics 2(6):239-253.

Harrison, M.D., C.E. Jones, M. Solioz, and C.T. Dameron. 2000. Intracellular $\mathrm{Cu}$ routing: The role of $\mathrm{Cu}$ chaperones. Trends Biol. Sci. 25:29-32.

Hirayama, T., J.J. Kieber, N. Hirayama, M. Kogan, P. Guzman, S. Nourizadeh, J.M. Alonso, W.P. Dailey, and A. Dancis. 1999. Responsive-to-antagonist1, a Menkes/Wilson disease-related $\mathrm{Cu}$ transporter, is required for ethylene signaling in Arabidopsis. Cell 97:383-393.

Horst, W.J. and H. Marschner. 1978. Effect of Si on manganese tolerance of bean plants (Phaseolus vulgaris L.). Plant Soil 50:287303.

Iwasaki, K., M. Fecht, P. Maier, and W.J. Horst. 2002a. Can leaf apoplastic manganese and $\mathrm{Si}$ concentrations explain Si-enhanced manganese tolerance of Vigna unguiculata (L.) Walp.? Dev. Plant Soil Sci. 92:246-247.

Iwasaki, K., P. Maier, M. Fecht, and W.J. Horst. 2002b. Effects of silicon supply on apoplastic manganese concentrations in leaves and their relation to manganese tolerance in cowpea [Vigna unguiculata (L.) Walp.]. Plant Soil 238:281-288.

Iwasaki, K., P. Maier, M. Fecht, and W.J. Horst. 2002c. Leaf apoplastic silicon enhances manganese tolerance of cowpea (Vigna unguiculata). J. Plant Physiol. 159:167-173.

Kampfenkel, K., S. Kushnir, E. Babiychuk, D. Inze, and M. Vanmontagu. 1995. Molecular characterization of a putative Arabidopsis thaliana copper transporter and its yeast homolog. J. Biol. Chem. 270:28479-28486.

Kaplan, M. 1999. Accumulation of $\mathrm{Cu}$ in soils and leaves of tomato plants in greenhouses in Turkey. Plant Nutr. 22:237-244.

Kegley, S., B. Hill, and S. Orme. 2007. PAN pesticides database. California pesticide use: Copper hydroxide. Pesticide use statistics for 2005. 8 May 2008. <http://www.pesticideinfo.org/Detail_ ChemUse.jsp?Rec_Id=PC33524>.

Kirkham, M.B. 2006. Cadmium in plants on polluted soils: Effect of soil factors, hyperaccumulation, and amendments. Geoderma 137:19-32.

Liang, Y.C., W.C. Sun, J. Si, and V. Römheld. 2005. Effects of foliarand root-applied $\mathrm{Si}$ on the enhancement of induced resistance to powdery mildew in Cucumis sativus. Plant Pathol. 54:678-685.

Lin, S.J. and V.C. Culotta. 1995. The ATX1 gene of Saccharomyces cerevisiae encodes a small metal homeostasis factor that protects cells against reactive oxygen toxicity. Proc. Natl. Acad. Sci. USA 92:3784-3788.

Lin, S.J., R.A. Pufahl, A. Dancis, T.V. O'Halloran, and V.C. Culotta. 1997. A role for the Saccharomyces ATX1 gene in Cu trafficking and iron transport. J. Biol. Chem. 272:9215-9220.

Ma, J.F. and N. Yamaji. 2006. Silicon uptake and accumulation in higher plants. Trends Plant Sci. 11:392-397. 
Maksimovic, J.D., J. Bogdanovic, V. Maksimovic, and M. Nikolic. 2007. Silicon modulates the metabolism and utilization of phenolic compounds in cucumber (Cucumis sativus L.) grown at excess manganese. J. Plant Nutr. Soil Sci. 170:739-744.

Marschner, H. 1995. Mineral nutrition of higher plants. 2nd ed. Academic Press, London.

Mills, H.A. and J.B. Jones, Jr. 1996. Plant analysis handbook II: A practical sampling, preparation, analysis, and interpretation guide. 1st ed. Micro-Macro Publishing, Athens, GA.

Nelson, M.R. 1988. Index to EPA methods. EPA Circular 901/3-88-01. U.S. Environmental Protection Agency, Washington, DC.

Neter, J., M.H. Kutner, C.J. Nachsheim, and W. Wasserman. 1996. Applied linear statistical models. 4th ed. Irwin, Chicago.

Puig, S. and D.J. Thiele. 2002. Molecular mechanisms of $\mathrm{Cu}$ uptake and distribution. Curr. Opin. Chem. Biol. 6:171-180.

Rees, E.M. and D.J. Thiele. 2004. From aging to virulence: Forging connections through the study of $\mathrm{Cu}$ homeostasis in eukaryotic microorganisms. Curr. Opin. Microbiol. 7:175-184.

Rensing, C. and G. Grass. 2003. Escherichia coli mechanisms of $\mathrm{Cu}$ homeostasis in a changing environment. FEMS Microbiol. Rev. 27: 197-213.

Rogalla, H. and V. Römheld. 2002a. Mechanism of Si-mediated manganese tolerance of Cucumis sativus L.: Effect of Si nutrition on manganese concentration in the intercellular washing fluid. Dev. Plant Soil Sci. 92:258-259.

Rogalla, H. and V. Römheld. 2002b. Role of leaf apoplast in siliconmediated manganese tolerance of Cucumis sativus L. Plant Cell Environ. 25:549-555.

Rogalla, H. and V. Römeheld. 2002c. Effects of silicon on the availability of boron: Possible effects on the phenol pathway and on the redox status in Cucumis sativus L., p. 205-213. In: H.E.
Goldbach, B. Rerkasem, M.A. Wimmer, P.H. Brown, M. Thellier, and R.W. Bell (eds.). Boron in plant and animal nutrition. Kluwer Academic/Plenum, New York.

Sancenón, V., S. Puig, I. Mateu-Andre's, E. Dorcey, D.J. Thiele, and L. Peñarrubia. 2004. The Arabidopsis copper transporter COPT1 functions in root elongation and pollen development. J. Biol. Chem. 279:15348-15355.

Sancenón, V., S. Puig, H. Mira, D.J. Thiele, and L. Peñarrubia. 2003. Identification of a $\mathrm{Cu}$ transporter family in Arabidopsis thaliana. Plant Mol. Biol. 51:557-587.

Scheck, H.J. and J.W. Pscheidt. 1998. Effect of Cu bactericides on Curesistant and -sensitive strains of Pseudomonas syringae pv. syringae. Plant Dis. 82:397-406.

Schuster, B. and J. Rétey. 1995. The mechanism of action of phenylanine ammonia-lyase: The role of prosthetic dehydrialaninedehydrolanine. Proc. Natl. Acad. Sci. USA 92:8433-8437.

Sharpless, K.E. and L.M. Gill. 2000. Value assignment of nutrient concentrations in 5 standard reference materials and 6 reference materials (2000). J. AOAC Int. 83:413-419.

Shikanai, T., P. Müller-Moulé, Y. Munekage, K.K. Niyogi, and M. Pilon. 2003. PAA1, a P-Type ATPase of Arabidopsis, functions in copper transport in chloroplasts. Plant Cell 15:1333-1346.

Williams, D.E. and J. Vlamis. 1957. The effect of silicon on yield and manganese-54 uptake and distribution in the leaves of barley plants grown in culture solutions. Plant Physiol. 32:404409.

Yoshida, S. 1965. Chemical aspects of the role of silicon in physiology of the rice plant. Bul. Natl. Inst. Agr. Sci. 15:1-58.

Zheng, Y.B., L.P. Wang, and M.A. Dixon. 2004. Response to copper toxicity for three ornamental crops in solution culture. HortScience 39:1116-1120. 